\title{
The Agency of Water and the Canal du Midi
}

\author{
Chandra Mukerji
}

Water is an underestimated tool of power. Its useful properties-what I would call agential properties - are so crucial to human life that hydraulic infrastructures can shape social relations and mediate power (Cronon 1992, 207-52; Lansing 1991). Water is used to power mills, carry boats, nourish animals, irrigate fields, take away refuse, and wash laundry. Water is not only necessary for the nourishment of living things, but it acts independently of human will in ways that can affect social possibilities. It flows and floods, evading capture and overcoming boundaries by flowing over and around them; or it can collect in low-lying areas, be tapped with wells, or disappear into the sand. Water's physical properties can be made to serve human communities through engineering, enhancing the agency of individuals or the powers of political regimes, but water can also be a trickster, defying or eluding human control. Both the powers of water and the difficulties in governing them are the reasons why hydraulic engineering can be a tool of power, or, more specifically, a legitimating means of impersonal rule.

The importance of water for public administration was made obvious in eventeenth-century France when the state authorized the construction of a canal through Languedoc-what would come to be called the Canal du Midi. The king, Louis XIV, indemnified land for the project, taking it away from local nobles, and the canal itself shifted the form of life around it, eroding traditional relations of power. It changed transport, manufacture, the location of mills, the movement of mail, and what people did with their laundry, in mundane ways altering the lives of people through the impersonal exercise of territorial governance.

In the roughly twenty years between 1663 and 1684, this navigational canal of 240 kilometers length and 50 locks was cut across Languedoc just north of the Pyrenees (Bergasse 1982-86; Mukerji 2009; Maistre 1998; Rolt 1973). The project was technically impossible according to the formal knowledge of hydraulics in the 
period, and so the waterway was a display of technical finesse so extraordinary that it was described after its completion as a "wonder of the world." The Canal du Midi was indeed surprising as it carried large boats across broad stretches of the region's arid landscape, floating on water that circulated around mountains and plains in ways water did not normally flow. In its own period, it was often called the Canal des Deux Mers, or the canal linking the two seas, because it crossed the continental divide, connecting the Garonne River near Toulouse (which was navigable to the Atlantic Ocean) to the Mediterranean Sea at a new port of Sète. It was a model of territorial governance and impersonal rule that stood for the king and his administration, but far from the person of the monarch.

The Canal du Midi was the most ambitious and expensive engineering project undertaken during the reign of Louis XIV, and was celebrated as evidence of the Sun King's ability to revive France's ancient engineering heritage and restore the glory of Gaul. It fit culturally with the king's ambitions for empire and propaganda efforts to equate France with Rome.

Material politics made sense in this period as Humanists revealed the greatness of Rome through things. Books and ruins were material remains that demonstrated how well the ancient empire deployed logistical powers for political ends. The French administration under Louis XIV's minister, Jean-Baptiste Colbert, studied these practices and tried to imitate them (Blair 2020; Miller 2000; Gébara and Michel 2002). Hydraulics had a central place in the cultural genealogy he was helping to draw from ancient Rome to modern France. Water was central to seventeenth-century understandings of Rome and to Colbert's policies of using engineering to empower the state at the Canal du Midi (Adkins and Adkins 1994; Long 2001).

Cutting a canal through Languedoc was also part of a broader political program to empower the monarchy using tools of impersonal rule. In Languedoc, turning to logistical politics was particularly important because the power of the northern monarch had become attenuated in that region during the Wars of Religion. Obedience to the sovereign was politically required, but not automatic for dissident nobles who routinely ignored or evaded the king's commands. It was this disobedience that spurred Colbert to seek alternative ways to enhance the power of the state, turning to material methods of territorial governance and legal practice that depersonalized relations to land and law (Mukerji 2007a). The resulting system has ironically been called state absolutism, or an enhanced form of personal rule. But Louis XIV's personal will was made more effective in this period only because the administration undercut the patrimonial order with impersonal forms of governance. ${ }^{1}$ State agents avoided, as much as possible, personal confrontations that the king's rivals could resist, and used legal precedents and infrastructural projects to transform a weak monarchy into state absolutism.

In this period of French patrimonial politics, power was supposed to circulate through social networks, not derive from the manipulation of landscapes, papers, and libraries. Royal policies were meant to be expressions of God's will, not the 
product of natural knowledge and earthly practices. As Kettering (1986) has shown, French patrimonial power was exercised through social networks cemented by the circulation of information and favors. And as Beik (1985) has argued, noble families enjoyed a high degree of autonomy within their regions, avoiding constraints by the state and king. The French monarchy was chronically weak as a result, and this became clear during the Fronde in Louis XIV's youth when powerful nobles and members of the bourgeoisie rose up against the government. Even though the Frondeurs were finally defeated, their strength had demonstrated the contingent nature of royal power in France. Thus, when Louis XIV took the throne, he stepped into a position of political vulnerability. It was Colbert's job to change this, which he did systematically and effectively, using techniques of impersonal rule.

Jacob Soll (2009) has identified one method Colbert used: the collection and analysis of historical legal documents. Soll argues that the clergy was a problem for Louis XIV as well as the nobility. Louis XIV did not have personal means to subordinate the French church to the crown, so Colbert established a legal basis, following the Roman practice of using legal archives to discipline the people exercising legal powers. France had been administered for much of the seventeenth century by clerics. Two long regencies during the minority of young kings, including Louis XIV, had put Cardinals Richelieu and Mazarin in charge of the French state, increasing the authority of the church over French politics and normalizing this through law. Colbert strove to rectify this situation not by confronting the clergy, but rather by undercutting them, using a form of impersonal power. $\mathrm{He}$ collected legal documents and employed a librarian to study them to establish through precedent the ultimate authority of French kings since Charlemagne over politics in France. Books and archives became administrative weapons of political warfare just as territorial engineering would, too.

This story of monarchical weakness and the turn to legal documentation to subordinate the clergy to the king was paralleled in Languedoc with construction of the Canal du Midi and the subordination of the regional nobility. The king's personal authority had become attenuated in the region, but the monarch still had rights to indemnify land and an obligation to act as steward of his kingdom, so he had the power to authorize construction of an infrastructure project that effectively reduced noble control over local land. Water and stone, like papers and books, were surprising but effective tools of government, and used in Languedoc for the subordination of king's rivals to the crown.

Languedoc was a region where the nobility and peasantry alike had become particularly independent of the crown. Languedoc had been bloodied by the wars of religion. Towns were taken and retaken by Catholics and Huguenots, as families were displaced, buildings razed, fields burned, and lives destroyed. Royal power had been used to crush Huguenot uprisings, creating a rift between the Catholic monarchy and the Huguenot nobles that dominated much of the region. Peace had come, but many members of the local elite still saw no reason to subordinate themselves to a king who stood for a religion they understood as corrupt. 
Elites had formal obligations to the monarch, but they were prone to ignore edicts from Paris (Holt 2001). Meanwhile, peasants used what James Scott has called the "weapons of the weak" (1985) to keep representatives of the king at bay, killing some tax collectors and threatening others (Froidour 1899; Mukerji 2009).

It was in this dissident, violent, and tumultuous region that a salt tax collector, Pierre-Paul Riquet, proposed to build a navigational canal to link the Mediterranean Sea to the Garonne River and the Atlantic Ocean. It was the perfect opportunity for Colbert to shake up local life by reworking the infrastructure. Riquet seemed an appropriate person for the project, too, because, as a tax farmer, he was already a contractor, doing dirty work for the state. He farmed the gabelle or salt tax, the most hated tax, and effectively brought in revenue in spite of local opposition. Riquet also proposed to build a canal wide enough to carry warships, not only explicitly allowing the French navy to move between the two seas without using the dangerous passage by Gibraltar, but also implicitly bringing the police power of the state to Languedoc in a permanent way.

Elites in this querulous corner of France opposed the project, assuming that their positions would be threatened and their land control compromised. But the project was as appealing to the king and Colbert as it was distasteful to locals. The minister had found a way to erode the habits of local life that sustained noble autonomy from the central government, giving the king new ways to impose his will on unruly subjects (Adgé 1992, 202-3; Mukerji 2009).

Riquet may have been a good salt tax collector, but he was no engineer. Still, he could imagine cutting a navigational canal across Languedoc because he traveled throughout the region on tax business and encountered local evidence of hydraulic sophistication. In the mountains and plains of Languedoc with dry summers and wet winters, water could be abundant or absent, so it was often captured at sources and rivers and channeled to where it was needed. Languedoc was riddled with ditches and diversionary channels that carried water towards towns, fields, and mills. A navigational canal seemed just a larger version of familiar cultural forms.

Languedoc was rich in hydraulic knowledge from the ancients because of the Roman bath towns that had been developed around the mountain hot springs in the Pyrenees. The baths were gone, but the hydraulic systems were being modified and used by peasant women for their own purposes, maintaining Roman knowledge of hydraulics but using it to supply water to public laundries and private homes (Mukerji 2008). Languedoc also had many mills, using diversionary canals for millstreams, and rivers that had been partly canalized and equipped with simple locks to bypass rapids. Some regions were also rich in diversionary channels used for irrigation, town water supplies, home water needs, and laundries. The region also had some engineering schools that taught the limited formal knowledge of hydraulics.

One of the faculty members from the school at Castres in the Montagne Noire, Pierre Borel, had even devised a plan to link Languedoc's major rivers with canals 
to create a navigational system for the whole region. The project only failed when Borel lost his job because he was a Huguenot; landholders would not give up their land to build his infrastructural project. Borel then went to Paris (Blanchard et al. 1985, 181-94).

Riquet had his own lands and a mill in the mountains near Castres, and he recognized the value of Borel's plan for integrating water systems. So the tax farmer, although he was not an engineer, nonetheless proposed building a navigational canal where Borel had imagined one. Riquet knew so little about hydraulics that he probably did not even know how complex a hydraulic system he was proposing or that it was technically impossible with the formal engineering knowledge of the period. He just assumed that Borel knew it was possible, and he believed in the skills of local laborers.

\section{WATER AND THE POLITICS OF IMPERSONAL RULE}

The story of the Canal du Midi is an interesting example of the turn to impersonal rule and the recruitment of water into French political administration. The completion of this waterway demonstrated conclusively that impersonal forms of governance could serve as a counter to patrimonial politics, depriving nobles of their control over the region by changing the hydrology.

Riquet was astonished by the political effectiveness of infrastructural change, and bragged to Colbert about how much he was doing for the king. He testified to the power of impersonal rule with this enthusiasm, but it was a political mistake, revealing his naïveté. In patrimonial terms, he was servant of the king, deriving his power to build the canal from the monarch, not giving power to the king. For this indiscretion, Riquet was politically marginalized and was branded by Colbert a dangerous man. But in noticing how the canal project was changing social life around him, he provided evidence of the efficacy of water as a tool of power (Mukerji 2009).

Social historians and sociologists, particularly those influenced by Marxism and world-systems analysis, ${ }^{2}$ have underscored the importance of land to power, but most social theories of power do not recognize water as an important political asset. ${ }^{3}$ Nonetheless, water supplies have historically been just as necessary to states as land. ${ }^{4}$ Moreover, water has numerous interesting properties and uses. Because water is a liquid, it acts quite unlike solids like rock and soil. It flows relentlessly downhill, so it can be used as a source of power for mills. And it floats boats, so it can serve as a medium for transportation. Alternately, it can cause floods, erode structures, destroy cities, and leave behind refuse and mud after a storm because it is an unruly material that defies easy control. So, water management raises distinctive engineering problems and possibilities for social life, and it can be an important source of social change-as it was at the Canal du Midi in seventeenthcentury France. 
Building the Canal du Midi gained political legitimacy in spite of local hostility to the project for cultural reasons. The restoration of nature through virtuous governance had religious sanction. It was the moral obligation of good Christians and virtuous leaders to restore the landscape to the perfection it had in the Garden of Eden. Making land more peaceful and productive was also deemed possible because Adam was made in God's image with a capacity to know his Creation. ${ }^{5}$

The idea of good stewardship and restoring nature to its Edenic form was powerful in many parts of Europe, and has often been identified as part of Protestant culture. Still in France, mesnagement stewardship politics was associated with religious tolerance, and pursued by Catholics and Protestants alike. If theologians disagreed about how to read the Bible, they could agree about how to govern the earth. It was the obligation of all descendants of Adam and Eve to try to undo the damage of the Fall. The English and Dutch used the idea of land stewardship to justify their overseas colonial activity. But the French focused mesnagement politics on the restoration of France itself after the ravages of the Wars of Religion. Olivier de Serres (1600) even argued that a king proved he was the true agent of God on earth when he used his God-given intelligence and moral fiber to restore the earth to its true form (Mukerji 2005; 2007a). In light of Serres's writing, Henri IV began to experiment with territorial governance, and Colbert later imitated these policies, considering cutting a navigational canal across Languedoc (Mukerji 2002; Pinsseau 1944).

Because it was a water channel, the Canal du Midi entered politics in an impersonal way. It was an agent of the state that could not be killed, but still had enormous influence over local life. It started to carry the mail, support wine production, link weavers to textile finishers, facilitate trade in leather, and integrate the region more politically. It also interrupted old ways of life, by cutting across roads and fields, destroying orchards and taking away business from mills. It also introduced money and a free labor market into a region that had been dominated by local estates and a peasant economy.

Locals who did not like the changes were faced with a problem because the canal was an agent of the state made of water, not flesh. They could resist the waterway by breaking down the sides of the channel where it was elevated, effectively stopping transport by stranding boats. But water would continue to flow out of any opening in the side of the canal, causing flooding downhill that would damage local towns and crops, while doing nothing to endanger the king or the power of the state. Water in the Canal du Midi became an uncanny sight and evidence of superhuman power, flowing far from any source, hugging the sides of mountains, and meandering through arid land. It stood for the state but far from the person of Louis XIV, illustrating the monarch's capacity to reshape Creation itself to serve as steward of his kingdom.

Exercising power using water eroded patterns of personal power because it worked by changing the context of life, not influencing social actors. It did not rely 
on social networks and patrimonial relations, so it evaded the techniques of control that regional nobles and clergy had cultivated for centuries. These elites had no obvious weapons with which to fight a conduit of water that spanned kilometers, crossing their land but also moving far beyond it. They had no powers to stop a king who had the right to indemnify lands for his own purposes, had a duty of good stewardship, and could impose new taxes to pay for infrastructural improvements. Under these conditions, water was a powerful weapon, and reshaped the lives of even those who vociferously opposed the will of the king.

\section{IT TAKES WATER TO FLOAT BOATS}

To look more closely at how the power of water was captured for the state and the Canal du Midi, I want to focus on the alimentation system that supplied water where the canal crossed the continental divide (Adgé 1992, 202-3). The navigational waterway would only work if it had a hydraulic system to bring water in the requisite quantities to the proper place, providing means for filling locks to raise and lower boats while managing water's unruly tendency to break out of channels or seep into the ground (Mukerji 2009).

A range of projects for a canal across Languedoc had been designed before Riquet proposed his project. The earliest ones were advanced by engineers who came to France from Italy, including Leonardo da Vinci. When François I gained control of Milan in 1515, he visited Lombardy, and was struck by the number and usefulness of the canals there. In 1516, he returned to France with Leonardo, and asked him whether it would be feasible to build a canal to connect the Garonne to the Aude River in Languedoc (Rolt 1973, 13-16; Gazelle 1985).

There was a long east-west valley north of the Pyrenees and south of the massif central that could - in principle-be spanned, using the Garonne to the west and the Aude to the east (figure 1.1). It was not as flat as the Lombardian plain, but could conceivably carry a canal. The problem, according to Leonardo, was finding a water supply (Rolt 1973, 16; Gazelle 1985, 147). The water supply was crucial to the project because the canal had to pass from the Mediterranean to the Atlantic watershed, crossing the continental divide or the pointe de partage des eaux, as it would be called. At this pointe de partage, water drained in two directions toward the two seas, and had to be replaced by water from a higher source. The question was where to get the water and how to deliver it to a canal through central Languedoc.

Riquet understood the problem of the water supply, and apparently liked Borel's solution: routing the canal itself through the mountains. Borel, when he had taught engineering at the university at Castres, had became familiar with a wide plain along the continental divide near Revel, where he thought he could build a canal joining rivers that flowed from this mountainous area in two directions: to the Atlantic Ocean and to the Mediterranean Sea (figure 1.2). This approach was counterintuitive because his canal would not follow the main east-west valley of Languedoc, but 


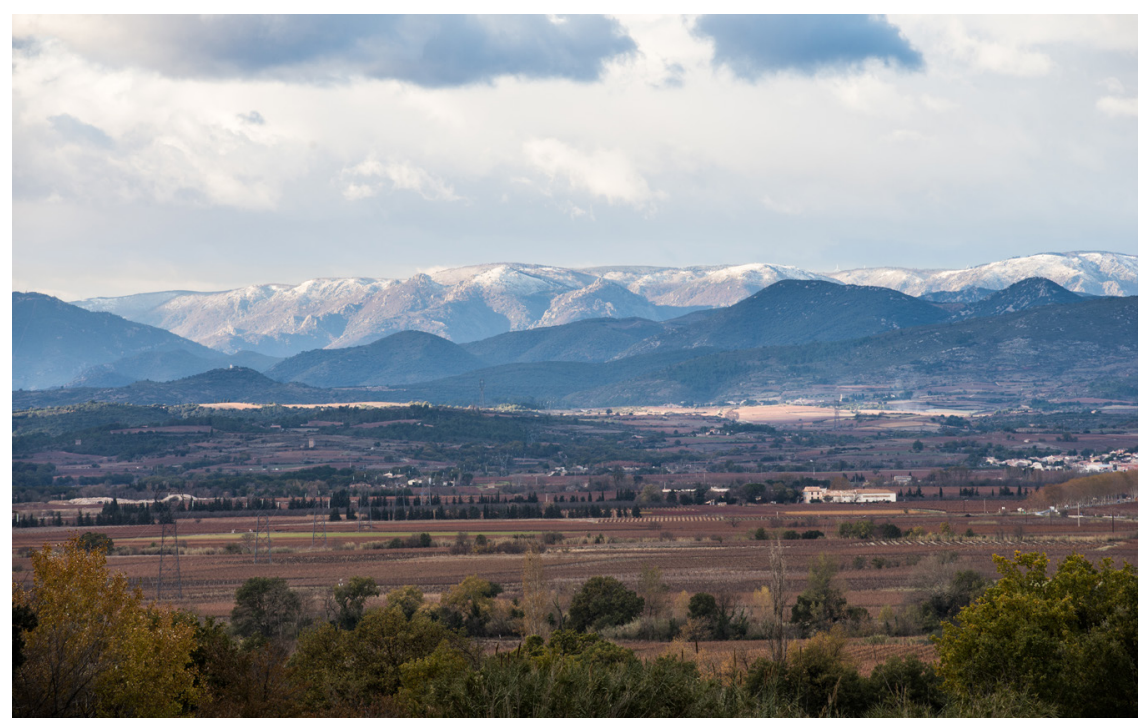

FIGURE 1.1. Valley in Languedoc below Montagne Noire. Photo courtesy Christian Ferrer.

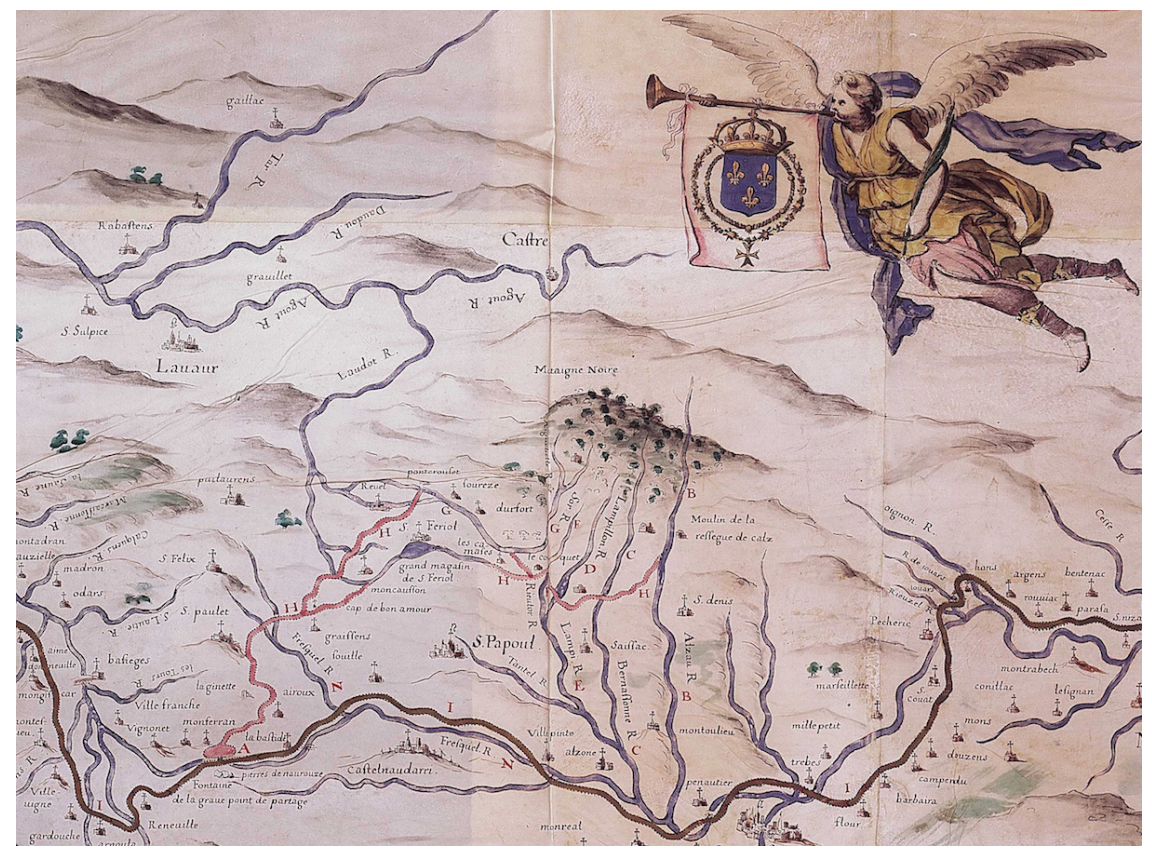

FIgURE 1.2. Region around Revel and Castres. Carte de la Partie ... du Canal. Photo courtesy le Service Historique de la Défense R21n9A. 
instead would veer north into the mountains before Toulouse. But a canal in this area could depend on water supplies from the nearby Montagne Noire.

Riquet never mentioned Borel or spoke of his proposals directly, but he worked on his idea for the canal with the Bishop of Castres, D'Anglure de Bourlemont, and in 1662 wrote Colbert to propose essentially Borel's plan. ${ }^{6}$ The proposal interested the minister, but Colbert wanted a commission of local notables and experts to evaluate it. He appointed the Chevalier de Clerville to head the commission, and Clerville, in turn, asked an engineer named Boutheroue, who managed the Canal de Briare near Paris, to work with Riquet to finalize a plan. Boutheroue insisted that the canal had to stay in the main valley of Languedoc and extend to the Garonne River near Toulouse, but he also thought that Riquet could use the route across the Revel plain to bring water from the Montagne Noire to supply the Canal du Midi (Mukerji 2009, 36-59).

This proposal was provisionally approved by the commission as long as Riquet could prove that the water supply was viable. The commission called for the entrepreneur to build a rigole d'essai, a smaller, trial version of the water supply system, to show how much water he could deliver from the Montagne Noire to the pointe de partage at the seuil de Naurouze. ${ }^{7}$ When the rigole was completed months later, the commission not only witnessed the arrival of water at Naurouze but was given a Relation particuliere de la rigolle dessay, a final report on the project describing how it was built. ${ }^{8}$

\section{THE RIGOLE D'ESSAI}

Examining the Relation particuliere de la rigolle dessay, one can get a very good picture of the work involved, although it was a bureaucratic document officially reporting to the commissioners what they already knew: Riquet had been able to bring adequate water to the pointe de partage at Naurouze. But the Relation was not simply verbal testimony, a procès-verbal written by men of rank and legal standing to testify to the success of an experiment. It was a relation, or a narrative accounting of what was done, why it took so long, what problems were encountered, and how the problems were solved. It was written anonymously by a nameless expert-a man who I think was Riquet's young assistant, Pierre Campmas. Campmas was the son of a local fontanier, and the person who had most centrally designed the water supply. Campmas was not a formally educated man, but rather a young recruit into a trade that he was learning from his father. He had neither the social standing nor the experience to give his word authority, but he was literate and knew enough to describe with precision the technical problems and solutions involved in the work.

The author of the Relation seems to have been Campmas because he said that people doubted his ideas on account of his being so young, but the rigole d'essai had worked, proving him right. The Relation particuliere de la rigolle dessay is also 
a technical document that describes in detail both the landscape of the Montagne Noire and how it was changed to bring water from high sources over the plain of Revel down to Naurouze. The author focuses on material agents like rocks and water, explaining how they normally interact in the mountain to produce its terrain, and he specifies how their powers were overcome or harnessed to build the rigole d'essai. The narrative of human power and powerlessness in the natural world would make particular sense to a rural fontanier whose job was to make recalcitrant water serve human purposes.

In the Relation, rocks impede access to places; water does what it wants, including disappearing into sand; soils change from place to place and pose different problems of construction and water-tightness. Riquet and his workers try to change relationships among things. Rocks are moved to let water flow downhill in a new direction. Routes are chosen so water will not flow too fast. The agency of people is used to control the agential properties of water. All the work is done on rocks, sand, and gravel, but the parameters of the work are set by the properties of water. Even the success of the canal builders is measured by the arrival of water from the rigole d'essai at the seuil de Naurouze. Water is preserved as an agential material because it is needed for floating boats and flowing through locks to the seas. Success entails the transfer of that agency to the state. Water is made a tool of impersonal rule.

Riquet began working on the rigole d'essai in May 1665, but progress was slow, so it was only completed in October. There were technical roadblocks and damaging floods that impeded the work. Water and rock kept following their own natures rather than submitting to the will of the king. Delivering water was no easy task because the mountain was wild and its sources were both high and remote. Also, the rigole had to cross the continental divide many times along the way, so keeping the inclines correct-a practice necessary to keep the water flowing-was not easy to assure. Building a watertight conduit in bad land was also no mean feat. So, while water could be diverted from streambeds near sources, what to do with it next was an ongoing problem.

Workers hit new springs in some places, or ran into small underground tunnels that sucked the water away. There were rocks and high scarps that stood between the mountain's high rivers and the main canal that had to be crossed without turning the rigole's waters into a waterfall that would tear the rigole apart. The Montagne Noire and its rivers had accommodated each other over centuries, creating a topography that defined them both. Now Riquet and the commissioners were asking water to follow new paths, and workers were trying to use natural materials to create unnatural effects (figure 1.3). Breaking down the habitual relationships of rocks, soil, and water in the Montagne Noire was an act of hubris. But it was also a means for capturing logistical power for the state, using the power of water to break down local social relations that had kept elites of Languedoc strikingly autonomous from the king. 


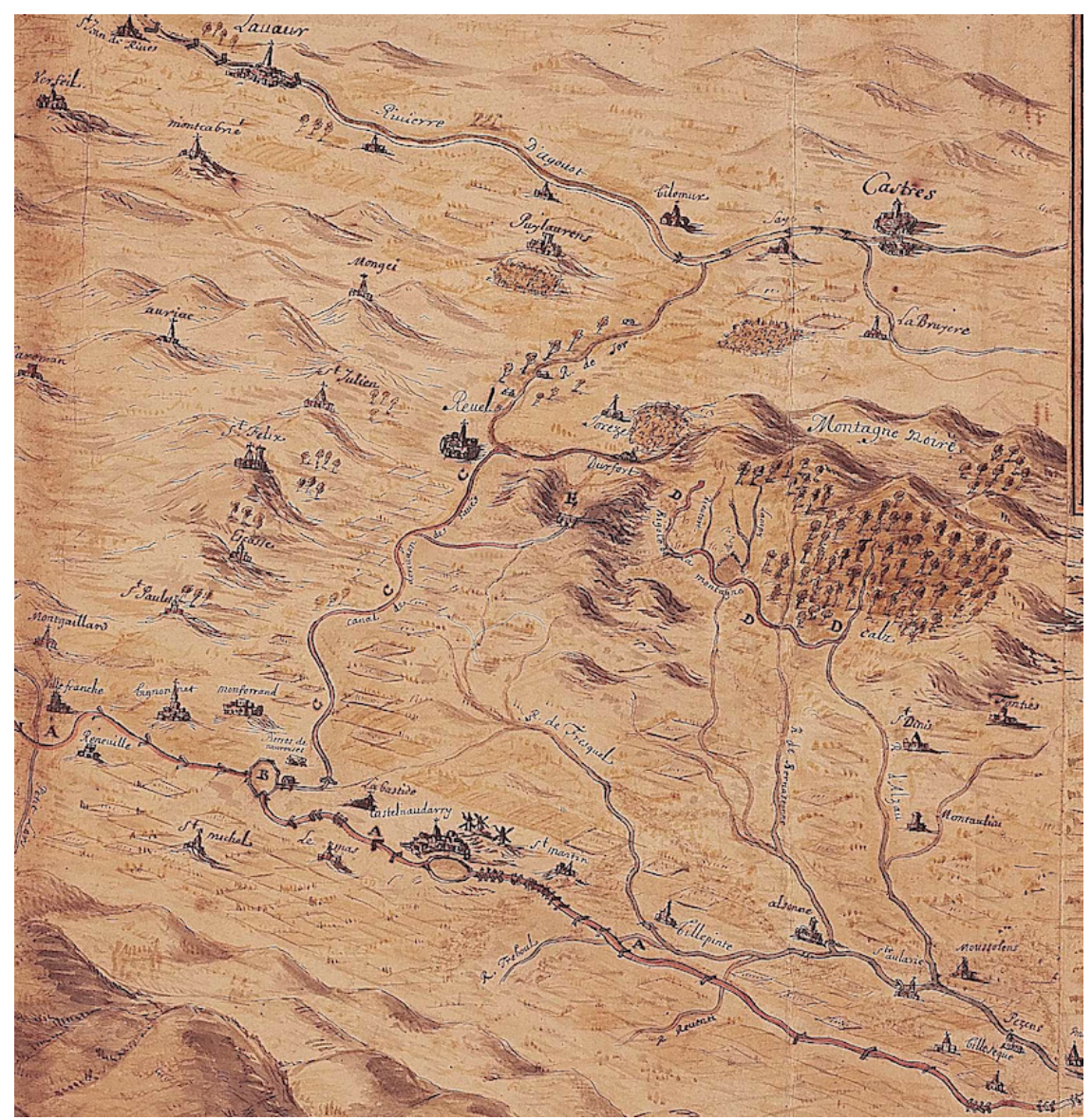

FIgURE 1.3. Proposed captures on the Montagne Noire. Carte du Canal Royal, 1677. Photo courtesy le Service Historique de la Défense R21n3oA.

The Relation particuliere de la rigolle dessay says that the test system for the water supply started at the Alzau River at a place called Calz. At this remote spot high in the mountains, river water gushed in a steady and strong flow. The location was so remote that it could not even be approached on horseback. Employment records show that Riquet used local men for this work (Adgé 2001), who apparently accessed this part of the mountain on foot. There were massive rocks at Calz that formed a deep ravine filled with sandy soil. There was no obvious way, the verification argued, to cut through the rocks or use the ravine without losing water. So, the crew built a wooden trough, presumably like the ones used for mills, to carry the water over the rocks and down through the ravine. ${ }^{9}$

Riquet, perhaps deciding that the whole rigole should be built this way, wrote to the horrified Colbert about this possibility, asking for permission to acquire 
masses of timber. ${ }^{10}$ But before the minister could say no, the entrepreneur wrote back that he had found another way to proceed. Perhaps the workers started blasting the rocks. The verification document mentions in a later section that they had run low on powder, so perhaps they had been using gunpowder for getting past rocks. ${ }^{11}$ What was rare in the mountain was a place where the soil was easy to dig, and a ditch would hold water by itself.

The water in the mountains kept responding to gravity more than the will of the king. If building the rigole was a matter of asserting human agency over the water, governing it through engineering, human agency was losing and the government seemed to have reached its logistical limits. Working with the materials at hand in the mountains, workers kept losing this elusive fluid rather than delivering it to the central valley of Languedoc. Both gravel and sand leaked water, sending it back to the rivers where it wanted to flow. Sand was easier to dig and could produce a nicely shaped ditch that could be reinforced with pilings, but often the rigole walls collapsed like sugar cubes into the currents when water started to flow. Sand often seemed to flow like a liquid along with the water it was supposed to contain.

Rocks made the terrain hard to traverse to get access to sources and impeded the construction of the rigole. Where there were large boulders or scarps, there was no hope of removing or moving them. Routes could be blasted through them using gunpowder, but this was hard, slow, and expensive work. The granite of the Montagne Noire paid the dividend, however, of providing strong, watertight material for the conduits. Sometimes workers used natural riverbeds as part of the rigole, adding more water from mountain sources and taking it out later where the conditions were less taxing. Many techniques were tried because the problems were varied and the inclines had to be precise no matter what type of terrain needed to be crossed. The rigole d'essai was a struggle with the solid materials of the mountains, but the parameters for its design were set by the demands of water itself.

Not all the technical problems were solved to create the rigole d'essai. The structure was provisional and remained leaky. The permanent rigoles made later were more watertight, lined in many places with a layer of pounded clay. Still, wooden pilings and planks, blasted rocks, and high berms shored up the experimental structure well enough to bring water in large quantities from the Montagne Noire across the plain of Revel and to the seuil de Naurouze.

In only one part of the Relation are workers criticized for the poor quality of their efforts. If the mountain and its materials created the problems in capturing water from high sources, faulty surveyors created the problems of routing on the plain of Revel. On this plain, the channel had to cross from the Atlantic to the Pacific watershed, but following the prescribed route, the water did not flow where the rigole had been dug. If most of the story in this report described human agents triumphing against the unruly forces of nature, at this point, where 


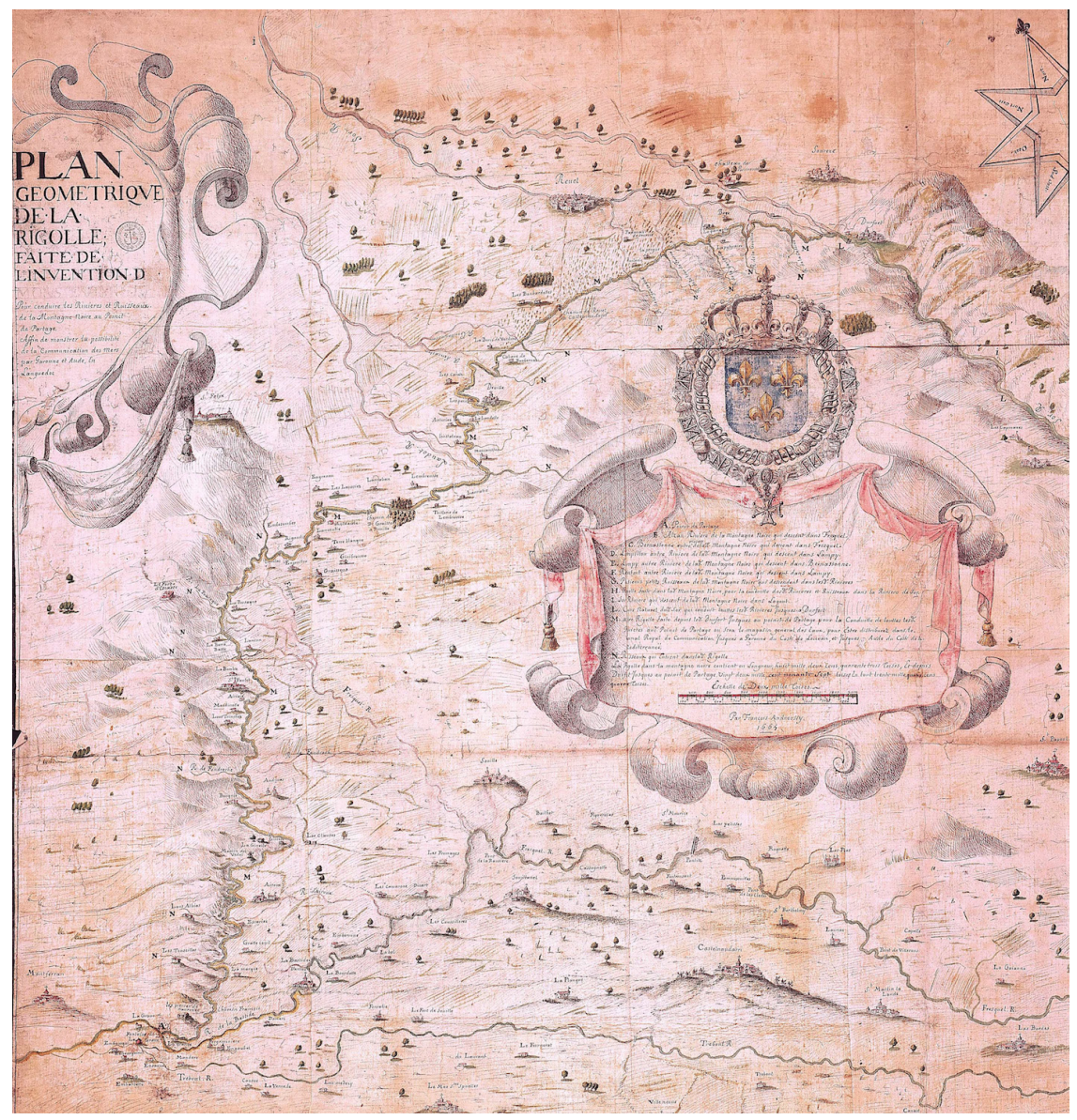

FIGURE 1.4. Area of the rigole d'essai. Andreossy map, 1665 Rigole de la plaine. Photo courtesy le Service Historique de la Défense R21n5A.

human intelligence was most necessary, it failed. But common sense prevailed, as the rigole was routed along millstreams that also crossed this divide.

Once the rigole left the plain of Revel, it passed down a long valley with good soil that was easy to dig, held its shape, and did not leak significant water. Attention to elevation remained crucial, since the water had to move by gravity feed alone toward the canal at the continental divide. The slopes were gentle, but the valley had hillocks to navigate around. In some places, the rigole was elevated with stone, wooden, and dirt berms to maintain its incline and remain above the level of the sieul de Naurouze (figure 1.4).

Along the way, the rigole picked up more water from local sources, helping restore some of what was lost on the mountainside. Naurouze itself had water 
sources that added to what was collected in the reservoir for the canal. So, by the time the rigole d'essai reached Naurouze, it brought a massive flow of water to this spot, a man-made river of sorts, that had circled down from the mountains, flowed into rivers and out, and skirted across the plains to provide alimentation for the Canal du Midi.

The test water supply system provided a calculable input of water into the Canal du Midi that was judged nearly adequate in itself for navigation in the dry summers of Languedoc. About a third of the water was thought to be lost but mostly recoverable in a permanent rigole. This proved to be an exaggeration, and the canal sometimes had to be closed in summer because of a lack of water. Still, the rigole d'essai was a massive success, and this assessment allowed Riquet to receive a contract for construction of the Canal du Midi.

The Relation ends with some congratulatory and celebratory remarks about Riquet's success. The report emphasizes that no one had really had a full sense of the complexity of the project of building the rigole, but that the concept remained correct and was shown to be viable. The author asserts that the verification vindicated him by demonstrating that his proposal was an honest one based on true knowledge. It shows him to be a person of honor, not just ability. He argues that he would not have proposed a project that was not feasible.

The final comments are an assertion of agency that associates the author's capacities to realize the rigole d'essai with the power of the human mind to exercise dominion over nature. Campmas, if he is the author, speaks in a language familiar to stewardship politics about the nature of logistical power. Forcing water from the mountain and taking it to Naurouze was an act of human dominion, and using it to build a peaceful waterway was an act of restoration, using the human intelligence given by God to Adam. Exercising logistical power, in this context, was not just a way to control people through the control of things, but a moral act of political efficacy. Descendants of Adam and Eve were supposed to tame wild nature and make it more serviceable, using Creation wisely.

The author defends his moral standing and personal honor by showing how Riquet's workforce made the water supply successful. Riquet and his workers could only exercise logistical power for the king by recognizing the properties of natural things like water and rock, using materials in the mountains to control the agential properties of water and make them serve a navigational canal to join the two seas. This was an act of stewardship.

The report was necessary to document to the commission how the system was built, but it was not the measure of its success. Success was demonstrated by material means with the flow of water at Naurouze. Everyone who saw the water arrive at this pass over the continental divide understood that Riquet's plan was viable. The blow-by-blow account of the hard work and technical difficulties involved only demonstrated the heroic dedication of Riquet and his men to make the water of the Montagne Noire serve Louis XIV. 


\section{CONCLUSION}

Building an effective hydraulic infrastructure was a means of asserting and legitimating a new kind of power-logistical power. France's weak state, which had for so long been unable to get local people to submit to the king, was now altering life in Languedoc in consequential and permanent ways. The water system demonstrated the impact of territorial governance, using natural forces to exercise the will of the king. The exact properties that made the water in the Montagne Noire so difficult to contain and deliver to the Canal du Midi also made the Canal du Midi a powerful force in the region. Once water started flowing through the canal, it was hard to stop.

Building the Canal du Midi was also a practice of impersonal governance that changed local life, shifting power away from local noble officials and landholders to agents of the state. Mills on rivers lost business to new ones along the canal. The roads managed by nobles were replaced for transport by the king's waterway. The mail came by boat on the canal; women washed laundry in it; and merchants traded in textiles, leathers, and wine. All this entangled local elites with the state administration that they had ignored before. Breaking apart rocks in the mountains and lining sandy conduits with clay put into the hands of the state a new capacity for shaping social life that was startlingly novel and powerful. Now the northern monarchy was not a distant distraction, but an unrelenting presence in Languedoc.

The Canal du Midi instantiated a new kind of power of the state: something superhuman, uncanny, and daunting - a technique of impersonal rule (Mukerji $2009,154-75)$. It was a work of logistical power, managing social relations by material means, and it was an impersonal instantiation of what a state could do. People in Languedoc may have understood that building the canal was the will of the king, but they were also witnesses to the physical labor and exercise of natural knowledge that made the canal work. And they were the ones whose lives began to change as nobles became landlords, renting land along the canal that renters planted with vineyards to make wine for export, and as new towns developed to take advantage of increased trade. The inhabitants of these towns and the cities along the canal were the ones who did their laundry in the canal's waters and found jobs in the new businesses, breaking down the peasant economy to replace it with a money system. Patterns of everyday life changed (Carroll 2006; Joyce 2003; Parker 1983; Scott 1998) without anyone telling people what to do. Logistical power worked silently outside social pressures and, in this sense, seemed apolitical even as it initiated social change.

The story of the reign of Louis XIV, particularly the tale of the growth of state absolutism, is usually told in terms of the king's life at Versailles (Apostolidès 1981; Neraudau 1986; Elias 1998; Mukerji 1997). But Louis XIV gained greater power over Languedoc through an exercise of stewardship of massive proportions that seemed to support the legitimacy of the northern monarchy. He seemed to be 
capable of fulfilling, too, France's destiny in restoring the glory of Gaul. The French were clearly able to engage in the kind of massive engineering work that had made Rome so powerful. This was not the only engineering to be touted in their period. There were the massive fortresses of Vauban and the new port cities along the Atlantic coast. France was changing, and so French life had to shift. Engineered by the state itself, life became French to fit the territory of the king. In this sense, the empowerment of the French state in the late seventeenth century is a story of impersonal rule, not personal rule. The state made Louis XIV seem absolutely powerful because it exercised powers that were not fully understood. It exercised the power of forestry, fortress engineering, archiving, book collecting, and bookkeeping. And in all these cases, politics was depersonalized as the agential properties of things were put to political use. Trees, stone, water, rags, and ink were the secret powers of administration that Colbert elaborated, and these were the impersonal tools he used to make the will of the king seem absolute. ${ }^{12}$

\section{ACKNOWLEDGMENTS}

Thank you to CASBS and UCHRI for funding in support of this research.

\section{REFERENCES}

Adgé, Michel. 1992. “Lart de l'hydraulique." In Canal royal de Languedoc: Le partage des eaux. Conseil d'architecture, d'urbanisme et de l'environment de la Haute-Garonne; Caue: Loubatières, 202-3.

- 2001. "Premier Etats du Barrage de Saint-Ferréol." Les Cahiers d'Histoire de Revel 7 .

Adkins, Lesley, and Roy Adkins. 1994. Handbook to Life in Ancient Rome. New York: Oxford University Press.

Anderson, Perry. 1974. Lineages of the Absolutist State. London: NLB.

Apostolidès, Jean-Marie. 1981. Le roi-machine: Spectacle et politique au temps de Louis XIV. Paris: Éditions de Minuit.

Appuhn, Karl. 2009. A Forest on the Sea: Environmental Expertise in Renaissance Venice. Baltimore: Johns Hopkins University Press.

Bartoli, Michel. 2011. "Louis de Froidour (1626-1685), Notre Héritage Forestier." Les Dossiers Forrestiers 23.

Beik, William. 1985. Absolutism and Society in Seventeenth-Century France: State Power and Provincial Aristocracy in Languedoc. Cambridge: Cambridge University Press.

Bergasse, Jean-Denis, ed. 1982-86. Le Canal du Midi. 4 vols. Cessenon: J.-D. Bergasse.

Blair, Ann. 2020. Too Much to Know: Managing Scholarly Information before the Modern Age. Hew Haven: Yale University Press.

Blanchard, Anne. 1979. Les ingénieurs du roy de Louis XIV à Louis XVI. Montpellier: Université Paul-Valéry.

Blanchard, Anne, Michel Adgé, and Jean-Denis Bergasse. 1985. "Les ingénieurs du roy." In Le Canal du Midi, edited by Jean-Denis Bergasse, 4:181-94. Cessenon: J.-D. Bergasse. 
Brewer, John. 1989. The Sinews of Power: War, Money and the English State, 1688-1783. New York: Knopf.

Carroll, Patrick. 2006. Science, Culture and Modern State Formation. Berkeley: University of California Press.

Cole, Charles Woolsey. 1964. Colbert and a Century of French Mercantilism. 2 vols. London: Cass.

Cronon, William. 1992. Nature's Metropolis: Chicago and the Great West. New York: W.W. Norton. de Froidour, Louis. 1899. Les Pyrenées Centrales au XVIIe siècle: Lettres écrites ... à M. de Héricourt . . e et à M. de Medon. Auch: G. Foix.

Dent, Julian. 1983. Crisis in Finance: Crown Financiers and Society in Seventeenth-Century France. New York: St. Martin's Press.

Drayton, Richard. 2000. Nature's Government: Science, Imperial Britain, and the "Improvement" of the World. New Haven: Yale University Press.

Elias, Norbert. 1998. The Court Society. New York: Pantheon.

Froidour, Louis de. 1899. Les Pyrenées centrales au XVIIe siècle; lettres écrites ... à M. de Héricourt ... et à M. de Medon. Auch,: Impr. et lithographie G. Foix.

Gazelle, François. 1985. "Riquet et les eaux de la Montagne Noire: Lidée géniale de l'alimentation du canal." In Le Canal du Midi, edited by Jean-Denis Bergasse, 4:143-70. Cessenon: J.-D. Bergasse.

Gébara, Chérine, and Jean-Marie Michel. 2002. "Laqueduc romain de Fréjus: Sa description, son histoire et son environnement." Revue Archéologique de Narbonnaise, supplement 33. Montpellier: Éditions de l'Association de la Revue Achéologique de Narbonnaise.

Holt, Mack P. 2001. The French Wars of Religion, 1562-1629. Cambridge: Cambridge University Press.

Joyce, Patrick. 2003. The Rule of Freedom: Liberalism and the City in Britain. London: Verso.

Kettering, Sharon. 1986. Patrons, Brokers and Clients in Seventeenth-Century France. New York: Oxford University Press.

Lansing, John. 1991. Priests and Programmers: Technologies of Power in the Landscape of Bali. Princeton: Princeton University Press.

Long, Pamela O. 2001. Openness, Secrecy, Authorship: Technical Arts and the Culture of Knowledge from Antiquity to the Renaissance. Baltimore: Johns Hopkins University Press.

Lynn, John. A. 1997. Giant of the Grand Siècle: The French Army, 1610-1715. Cambridge: Cambridge University Press.

Maistre, André. 1998. Le Canal des Deux-Mers: Canal Royal du Languedoc, 1666-1810. Toulouse: E. Privat.

Mann, Michael. 1986. Sources of Social Power. New York: Cambridge University Press.

Miller, Peter N. 200o. Peiresc's Europe: Learning and Virtue in the Seventeenth Century. New Haven: Yale University Press.

Minard, Philippe. 1998. La fortune du colbertisme: État et industrie dans la France des Lumières. Paris: Fayard.

Mousnier, Roland. 1979. The Institutions of France under the Absolute Monarchy, 1598-1789: Society and the State. Translated by Brian Pearce. Chicago: University of Chicago Press.

Mukerji, Chandra. 1997. Territorial Ambitions and the Gardens of Versailles. Cambridge: Cambridge University Press. 
2002. "Material Practices of Domination: Christian Humanism, the Built Environment and Techniques of Western Power." Theory and Society 31: 1-34.

- 2005. "Dominion, Demonstration and Domination: Religious Doctrine, Territorial Politics, and French Plant Collection." In Colonial Botany: Science, Commerce, and Politics in the Early Modern World, edited by Londa Schiebinger and Claudia Swan, 19-33. Philadelphia: University of Pennsylvania Press.

2007a. "Demonstration and Verification in Engineering." In The Mindful Hand: Inquiry and Invention from the Late Renaissance to Industrialization, edited by Lissa Roberts, Simon Schaffer, and Peter Dear, 169-88. Chicago: University of Chicago Press. - 2007b. "The Great Forest Survey of 1669-1671." Social Studies of Science 37 (2): $227-53$.

- 2008. "Women Engineers and the Culture of the Pyrenees." In Making Knowledge in Early Modern Europe: Practices, Objects and Texts, 1400-180o, edited by Pamela Smith and Benjamin Schmidt, 19-44. Chicago: University of Chicago Press.

- 2009. Impossible Engineering: Technology and Territoriality on the Canal du Midi. Princeton: Princeton University Press.

Murat, Inès. 1984. Colbert. Translated by Robert Francis Cook and Jeannie Van Asselt. Charlottesville: University Press of Virginia.

Neraudau, Jean-Pierre. 1986. L'Olympe du Roi Soleil. Paris: Société des Belles-Lettres.

Parker, David. 1983. The Making of French Absolutism. London: Edward Arnold.

Pinsseau, Pierre. 1944. Le Canal Henri IV ou Canal de Briare (1604-1943). Orléans: R. Houzé. Rolt, L.T.C. 1973. From Sea to Sea: The Canal du Midi. London: Penguin.

Scott, James. 1985. Weapons of the Weak. Everyday Forms of Peasant Resistance. New Haven: Yale University Press.

1998. Seeing like a State: How Certain Schemes to Improve the Human Condition Have Failed. New Haven: Yale University Press.

Scott, Joseph Frederick. 2006. The Scientific Work of René Descartes, 1596-1650. Ann Arbor: University of Michigan Press.

Serres, Olivier de. 160o. Le Théâtre d'Agriculture et Mesnage des Champs. Paris: I. Métayer. Soll, Jacob. 2009. The Information Master: Jean-Baptiste Colbert's Secret State Intelligence System. Ann Arbor: University of Michigan Press.

Tilly, Charles. 1975. The Formation of National States in Western Europe. Princeton: Princeton University Press.

Wallerstein, Immanuel. 1974. The Modern World System. New York: Academic Press.

\section{NOTES}

The documents cited here (ACM) are from the Archives du Canal du Midi operated by the Voies Navigables de France in Toulouse, and managed by the archivist, Samuel Vannier.

1. Most writers on Colbert emphasize his economic policies to the exclusion of his other experiments in material governance. See, for example, the classic: Cole (1964). See also Murat (1984); Minard (1998); and Dent (1983).

2. See, for example, Carroll (2006); Joyce (2003); Mann (1986); Parker (1983); Scott (1998); Tilly (1975); and Wallerstein (1974).

3. Michael Mann (1986) even speaks of logistics. 
4. See Lansing (1991) and Cronon (1992). See also the interconnectedness of water-based power and land control in Appuhn (2009).

5. See, for example, Drayton (2000).

6. Mukerji (2009, 43-48); Rolt (1973, 24-26). Pierre Borel went on to Paris when he left Languedoc and became quite well known. He entered the Académie Royale des Sciences as a chemist and wrote on Cartesian science. See Scott $(2006,84)$.

7. ACM 2-14; Mukerji (2009, 56-59); letter from Riquet to Colbert, August 18, 1665, ACM 20-21.

8. ACM 2-14.

9. ACM 2-14, pp. 1-2.

10. Letter from Riquet to Colbert, September 3, 1665, ACM 20-19.

11. ACM 2-14, p. 11.

12. Blanchard (1979); Bartoli (2011). Compare to Appuhn (2009). 